\title{
INSTITUTIONAL SUPPORT OF MODERNIZATION OF YOUNG MARKET ECONOMIES
}

\section{Tiutiunnikova Svitlana ${ }^{1}$ \\ Mykytas Viktoriia ${ }^{2}$}

DOI: https://doi.org/10.30525/978-9934-571-78-7_15

Abstract. Modern world economy is characterized by the swift processes of globalization. National economies meet with the challenges of vagueness in relation to include of them in global space. Integration processes take place constantly, every country develops exactly on such conditions. Globalization comes forward as a plane of forming of economic politics of the state. On such conditions creation of factors and mechanisms of recreation of the national economic system becomes actual on the basis of combination of endogenous and exogenous sources and factors of development. There are not clearly certain consequences of globalization. These consequences can be both positive and negative for an economy of countries and its further development. The crisis phenomena distribute operating on all space of globalization, in fact, unifying processes, create dependence of economies of different countries one from other. On such conditions a clear theoretical comprehension and understanding of economic politics of the state in creating of strong institutional environment, its place and role, become important in a difficult integration process. The state economic policy has an important value for development of economy of every country of the world. It shows by itself the aggregate of interconnected actions of the state on creation of scope terms of development of economy by achievement of the put aims, perfection of economic parameters of providing of stable, effective public recreation. In the conditions of global structural changes an economic policy is transformed, importance and effectiveness of longterm aims of creation of competitive housekeeper and high quality of life of population increases in it. The influence of globalization on economic

\footnotetext{
${ }^{1}$ Doctor of Economic Sciences, Professor of Department of Economic Theory and Economic Methods of Management, V.N. Karazin Kharkiv National University, Ukraine

${ }^{2}$ Candidate of Economic Sciences, Assistant Professor of Department of Economic Theory and Economic Methods of Management, V.N. Karazin Kharkiv National University, Ukraine

(C) Tiutiunnikova Svitlana, Mykytas Viktoriia
} 
position of country is determined by the complex of contradictory factors including by a mestome in the international division of labor, by quality of institutes and others like that. Foreground job for state economic policy is forming of national strategy of socio-economic development, capable, becomes in such terms, using positive possibilities of globalization, to provide the organic plugging of economy of country in global reproductive processes.

\section{Introduction}

The modern context of socio-economic development is determined by complicated and contradictory processes of transition to a digital economy and the information society, increasing development imbalances and urbanization, growing inequality and fundamental uncertainty. The world has become complete, interpenetrable and interdependent. As a result, the institutional regime that is taking shape in the international arena and at the level of national economies becomes especially relevant.

Socio-economic development is particularly difficult in countries that have recently embarked on the path of market reformatting of their economies.

To enter the circle of developed countries with a high level of welfare, these countries need to implement their national modernization project. Its goal is to create a structurally verified innovative economy. Institutional transformations carried out by these countries should be adjusted, coupled with the institutional changes which are dictated by global trends and have been adapted in world practice. Today, opportunistic behavior of any is fraught with increased instability and instability of world development.

The humanistic component of modern development is focused on the person, development of his potential, empowerment for the long and happy life. Not coincidentallyб the quality of institutions is at the center of attention of theorists and practitioners.

Countries that have made the transition to a market economy in recent decades have fallen into a zone of turbulence. The joint imposition of civilizational transformations and internal deep transformations have led to the need to establish an active innovative role of the state in creating a new institutional regime.

In the framework of solving the most important current problems of the socio-economic development of these countries, the problem of economic 


\section{Chapter «Economic sciences»}

modernization, the search for innovative solutions and mechanisms for innovative development are particularly acute. Only through innovation can the quality of socio-economic development be influenced by radical changes in structural and technological changes in the economy and society.

The integration efforts to European cooperation of countries such as Ukraine produce the need to bridge the gaps with EU countries in innovative development and quality of life. Institutional changes are aimed to the mutual coordination of the industrial, technological, innovation and social policies pursued.

Institutional changes should be aimed to the creating conditions for such modification of the economic sovereignty of countries that would allow them to make strategic decisions based on the primacy of national interests and socio-economic development goals.

\section{The role of globalization in development of effective national economy}

In the conditions of global structural changes, the requirement increased in complex effective state economic policy in realization of aims of effective development of economic subjects and state is increased, passing to the market economy of some countries of the world. The system of state support of managing subjects in Ukraine is not effective enough and does not provide to a full degree economic, legal, organizational and informative terms for functioning of institutional environment, what would assist to steady economic development and guaranteed the stable rates of the economy growing. Ukraine, as well as countries with an immature economy, needs, foremost, state economic policy, that would assist to creation of the effective competitive social oriented economy with strong institutional environment.

Difficult problems that appeared to Ukraine in the context of post-crisis renewal of economy inclusive socio-economic development, increase of strategic capability of the state, stipulated the necessity of theoretical improvement of essence, maintenance, role and place of economic policy for society, determination of features of economic state policy at modern conditions.

Researchers constantly engage in the question of forming and realization of effective economic policy. Under modern circumstances of forming and realization of economic politics of the state becomes complicated 
by swift development of dynamic processes of globalization, that creates the necessity of consideration of state economic policy for the context of globalization and leading out of parameters of it effective functioning.

Globalization not only strengthens the world economic copulas and international co-operation, assists to development of multinational corporations, upper state and interregional administrative structures, organs and institutes, intergovernmental public associations, but also results in the change of role of the national state under act of variable and correcting each other processes and phenomena. Such situation not only activates the task of methodological ground of state economic policy but also pulls out a requirement to the criteria of estimation of its efficiency [9].

Globalization has become the result of the functioning of the modern international economy and the scientific and technical, including information, revolution: the global processes taking place between the states and regions of the world, above all, is a consequence of the freedom and the speed of the implementation of international transactions through the computerization, the Internet, mobile communication, etc. [10, p. 12].

Some analysts believe that globalization opens the era of the disappearance of national states: "The era of nation-states began at a time when the political institutions were prioritized over the religious wars that culminated in the Westphalian treaties. This era is coming to an end, and the pessimists have every reason to assert that we may be drawn into a period similar to that which preceded the Westphalian settlement - in the times of the great rigor and religious wars" [5, p. 22]. However, the author does not see anything caused in the events of the late 20th century: "The logic of the emerging world weakens the mediating structures and adds a powerful impetus and influence to individual people and non-state actors (the world scene). For some, this new freedom is an issue of concern, it can lead to religious fundamentalism or fanaticism, they believe. However, such freedom also opens new opportunities for an individual initiative and unlimited increase in the flexibility of the global system. Considerably more active actors make decisions that compete with each other, which then encountering a global scale through attempts and errors, lead to a positive result for everybody" [5, p. 22].

Global risks are intensifying but the collective will to tackle them appears to be lacking. Instead, divisions are hardening. The world's move into a new phase of state-centred politics, noted in last year's Global Risks Report [18], continued 


\section{Chapter «Economic sciences»}

throughout 2018. The idea of "taking back control" - whether domestically from political rivals or externally from multilateral or supranational organizations resonates across many countries and many issues. Regarding to this report all global risks can be divided into 5 groups (Table 1).

Globalization has a contradictory effect on the national economic power of the states manifested in the contradictions between resources generated by globalization and their asymmetric local concentration; between the increasing complexity of tasks in the context of the spread of global challenges and risks and the limited national capabilities in their solution; between the tendencies of socialization and humanization the vector of civilization transformation and the spread of opposite tendencies the deepening of social inequality, the growth of uncontrolled conflict, massive spontaneous migration.

Table 1

Global risks according to the Global Risks Report 2019

\begin{tabular}{|l|l|}
\hline \multicolumn{2}{|c|}{ Economic: } \\
\hline $\begin{array}{l}\text { Asset bubbles in a } \\
\text { major economy }\end{array}$ & $\begin{array}{l}\text { Unsustainably overpriced assets such as commodities, } \\
\text { housing, shares, etc. in a major economy or region }\end{array}$ \\
\hline $\begin{array}{l}\text { Deflation in a major } \\
\text { economy }\end{array}$ & $\begin{array}{l}\text { Prolonged near-zero inflation or deflation in a major economy } \\
\text { or region }\end{array}$ \\
\hline $\begin{array}{l}\text { Failure of a major } \\
\text { financial mechanism } \\
\text { or institution }\end{array}$ & $\begin{array}{l}\text { Collapse of a financial institution and/or malfunctioning of a } \\
\text { financial system that impacts the global economy }\end{array}$ \\
\hline $\begin{array}{l}\text { Failure/shortfall of } \\
\text { critical infrastructure }\end{array}$ & $\begin{array}{l}\text { Failure to adequately invest in, upgrade and/or secure } \\
\text { infrastructure networks (e.g. energy, transportation and } \\
\text { communications), leading to pressure or a breakdown with } \\
\text { system-wide implications }\end{array}$ \\
\hline $\begin{array}{l}\text { Fiscal crises in key } \\
\text { economies }\end{array}$ & $\begin{array}{l}\text { Excessive debt burdens that generate sovereign debt crises } \\
\text { and/or }\end{array}$ \\
\hline \multicolumn{1}{|c|}{ liquidity crises } \\
\hline $\begin{array}{l}\text { High structural } \\
\text { unemployment or } \\
\text { underemployment }\end{array}$ & $\begin{array}{l}\text { A sustained high level of unemployment or underutilization } \\
\text { of the productive capacity of the employed population }\end{array}$ \\
\hline \multicolumn{2}{|c|}{$\begin{array}{l}\text { Large-scale activities outside the legal framework such } \\
\text { as illicit financial flows, tax evasion, human trafficking, } \\
\text { counterfeiting and/or organized crime that undermine social } \\
\text { interactions, regional or international collaboration, and } \\
\text { global growth }\end{array}$} \\
\hline
\end{tabular}




\begin{tabular}{|c|c|}
\hline & Table 1 continuation \\
\hline $\begin{array}{l}\text { Severe energy price } \\
\text { shock (increase or } \\
\text { decrease) }\end{array}$ & $\begin{array}{l}\text { Significant energy price increases or decreases that place } \\
\text { further economic pressures on highly energy-dependent } \\
\text { industries and consumers }\end{array}$ \\
\hline $\begin{array}{l}\text { Unmanageable } \\
\text { inflation }\end{array}$ & $\begin{array}{l}\text { Unmanageable increases in the general price levels of goods } \\
\text { and services in key economies }\end{array}$ \\
\hline \multicolumn{2}{|l|}{ Environmental: } \\
\hline $\begin{array}{l}\text { Extreme weather } \\
\text { events }\end{array}$ & $\begin{array}{l}\text { Major property, infrastructure, and/or environmental damage } \\
\text { as well as loss of human life caused by extreme weather } \\
\text { events }\end{array}$ \\
\hline $\begin{array}{l}\text { Failure of climate- } \\
\text { change mitigation and } \\
\text { adaptation }\end{array}$ & $\begin{array}{l}\text { The failure of governments and businesses to enforce or } \\
\text { enact effective measures to mitigate climate change, protect } \\
\text { populations and help businesses impacted by climate change } \\
\text { to adapt }\end{array}$ \\
\hline $\begin{array}{l}\text { Major biodiversity } \\
\text { loss and ecosystem } \\
\text { collapse }\end{array}$ & $\begin{array}{l}\text { Irreversible consequences for the environment, resulting } \\
\text { in severely depleted resources for humankind as well as } \\
\text { industries }\end{array}$ \\
\hline $\begin{array}{l}\text { Major natural } \\
\text { disasters }\end{array}$ & $\begin{array}{l}\text { Major property, infrastructure, and/or environmental damage } \\
\text { as well as loss of human life caused by geophysical disasters } \\
\text { such as earthquakes, volcanic activity, landslides, tsunamis, } \\
\text { or geomagnetic storms }\end{array}$ \\
\hline $\begin{array}{l}\text { Man-made } \\
\text { environmental } \\
\text { damage and disasters }\end{array}$ & $\begin{array}{l}\text { Failure to prevent major man-made damage and disasters, } \\
\text { including environmental crime, causing harm to human lives } \\
\text { and health, infrastructure, property, economic activity and the } \\
\text { environment }\end{array}$ \\
\hline \multicolumn{2}{|l|}{ Geopolitical: } \\
\hline $\begin{array}{l}\text { Failure of national } \\
\text { governance }\end{array}$ & $\begin{array}{l}\text { Inability to govern a nation of geopolitical importance as a } \\
\text { result of weak rule of law, corruption or political deadlock }\end{array}$ \\
\hline $\begin{array}{l}\text { Failure of regional or } \\
\text { global governance }\end{array}$ & $\begin{array}{l}\text { Inability of regional or global institutions to resolve issues of } \\
\text { economic, geopolitical, or environmental importance }\end{array}$ \\
\hline $\begin{array}{l}\text { Interstate conflict } \\
\text { with regional } \\
\text { consequences }\end{array}$ & $\begin{array}{l}\text { A bilateral or multilateral dispute between states that } \\
\text { escalates into economic (e.g. trade/currency wars, resource } \\
\text { nationalization), military, cyber, societal, or other conflict }\end{array}$ \\
\hline $\begin{array}{l}\text { Large-scale terrorist } \\
\text { attacks }\end{array}$ & $\begin{array}{l}\text { Individuals or non-state groups with political or religious } \\
\text { goals that successfully inflict large-scale human or material } \\
\text { damage }\end{array}$ \\
\hline $\begin{array}{l}\text { State collapse or } \\
\text { crisis }\end{array}$ & $\begin{array}{l}\text { State collapse of geopolitical importance due to internal } \\
\text { violence, regional or global instability, military coup, civil } \\
\text { conflict, failed states, etc. }\end{array}$ \\
\hline $\begin{array}{l}\text { Weapons of mass } \\
\text { destruction }\end{array}$ & $\begin{array}{l}\text { The deployment of nuclear, chemical, biological, and } \\
\text { radiological technologies and materials, creating international } \\
\text { crises and potential for significant destruction }\end{array}$ \\
\hline
\end{tabular}


End of Table 1

\begin{tabular}{|l|l|}
\hline \multicolumn{2}{|c|}{ Societal: } \\
\hline $\begin{array}{l}\text { Failure of urban } \\
\text { planning }\end{array}$ & $\begin{array}{l}\text { Poorly planned cities, urban sprawl and associated } \\
\text { infrastructure that create social, environmental and health } \\
\text { challenges }\end{array}$ \\
\hline Food crises & $\begin{array}{l}\text { Inadequate, unaffordable, or unreliable access to appropriate } \\
\text { quantities and quality of food and nutrition on a major scale }\end{array}$ \\
\hline $\begin{array}{l}\text { Large-scale } \\
\text { involuntary migration }\end{array}$ & $\begin{array}{l}\text { Large-scale involuntary migration induced by conflict, } \\
\text { disasters, environmental or economic reasons }\end{array}$ \\
\hline $\begin{array}{l}\text { Profound social } \\
\text { instability }\end{array}$ & $\begin{array}{l}\text { Major social movements or protests (e.g. street riots, social } \\
\text { unrest, etc.) that disrupt political or social stability, negatively } \\
\text { impacting populations, and economic activity }\end{array}$ \\
\hline $\begin{array}{l}\text { Rapid and massive } \\
\text { spread of infectious } \\
\text { diseases }\end{array}$ & $\begin{array}{l}\text { Bacteria, viruses, parasites, or fungi that cause uncontrolled } \\
\text { spread of infectious diseases (for instance as a result of } \\
\text { resistance to antibiotics, antivirals and other treatments) } \\
\text { leading to widespread fatalities and economic disruption }\end{array}$ \\
\hline Technological: & $\begin{array}{l}\text { A significant decline in the available quality and quantity of } \\
\text { fresh water, resulting in harmful effects on human health and/ } \\
\text { or economic activity }\end{array}$ \\
\hline $\begin{array}{l}\text { Adverse } \\
\text { consequences } \\
\text { of technological } \\
\text { advances }\end{array}$ & $\begin{array}{l}\text { Intended or unintended adverse consequences of } \\
\text { technological advances such as artificial intelligence, } \\
\text { geo-engineering and synthetic biology causing human, } \\
\text { environmental, and economic damage }\end{array}$ \\
\hline $\begin{array}{l}\text { Breakdown of } \\
\text { critical information } \\
\text { infrastructure and } \\
\text { networks }\end{array}$ & $\begin{array}{l}\text { Cyber dependency that increases vulnerability to outage of } \\
\text { critical information infrastructure (e.g. internet, satellites, } \\
\text { etc.) and networks, causing widespread disruption }\end{array}$ \\
\hline $\begin{array}{l}\text { Large-scale cyber- } \\
\text { attacks }\end{array}$ & $\begin{array}{l}\text { Large-scale cyber-attacks or malware causing large economic } \\
\text { damages, geopolitical tensions, or widespread loss of trust in } \\
\text { the internet }\end{array}$ \\
\hline $\begin{array}{l}\text { Massive incident of } \\
\text { data fraud/theft }\end{array}$ & $\begin{array}{l}\text { Wrongful exploitation of private or official data that takes } \\
\text { place on an unprecedented scale }\end{array}$ \\
\hline
\end{tabular}

The ultimate objective of national economic performance is broad-based and sustained progress in living standards, a concept that encompasses wage and non-wage income (e.g., pension benefits) as well as economic opportunity, security and quality of life. This is the bottom-line basis on which a society evaluates the economic dimension of its country's leadership. Many countries have had difficulty in satisfying social expectations in this regard. For example, in the last five years, annual median incomes declined 
by $2.4 \%$ in advanced economies, while GDP per capita growth averaged less than $1 \%$.

However, inclusive growth is more than that. An economy is not a business, and history and scholarship have shown that there is a feedback loop between the bottom- and top-lines (growth and equity) in a national economy. This feedback loop can run in either a positive or a negative direction. The extent to which it is a virtuous circle is influenced by a diverse mix of structural and institutional aspects of economic policy, going well beyond the two areas most commonly featured in discussions about inequality: education and redistribution [19].

The policy and institutional domains portrayed in this Framework represent the ecosystem of structural policy incentives and institutions that together and as part of the growth process help to diffuse widely the benefits of an expanding national economy in terms of household income, opportunity, economic security, and quality of life. This ecosystem constitutes the implicit income distribution system or, more precisely, living-standards diffusion mechanism - underpinning modern market economies. When functioning properly, it operates in a self-reinforcing cycle in which economic growth and social inclusion feed each other.

The prevalence of systemic corruption and low levels of trust and integrity continues to widen and deepen societal fissures, exacerbate inequality and impede the efficacy of both public and private investment. Illicit financial flows cost developing countries $\$ 1.26$ trillion each year, and have a substantial impact on developed economies: it is estimated that the EU loses more than $\$ 159$ billion each year to corruption [4]. Growing evidence suggests that "corruption both feeds on and is fed by the broader crisis of trust, which sustains a vicious cycle that undermines economic health and social cohesion" [3]. One of the biggest challenges now for leaders globally is ensuring that anti-corruption efforts contribute to building trust, thereby maintaining economic and political stability.

The World Economic Forum's Partnering Against Corruption Initiative (PACI) launched the Future of Trust and Integrity project to examine how to rebuild trust and integrity while simultaneously addressing corruption. When trust and integrity are built into systems, they support a more predictable operating environment, which in turn helps establish a level playing field for all stakeholders. 
The Future of Trust and Integrity project has identified three key dimensions of trust and integrity - institutional, behavioral and technological dimensions - to effect positive change in corrupt systems (Figure 1). To ensure applicability, the project presents case studies demonstrating where business, government and civil society have successfully improved levels of trust and integrity to address corruption.

During the last few years there was the ambiguous and ineffective system of institutes in Ukraine. Speaking about the necessary system of institutes, which would be instrumental in forming and realization of effective economic state policy, it should be remembered that, from one side, effective institutes positively influence on the economy growing through minimization of risks of vagueness, decline of informative asymmetry and increase of macroeconomic stability. But, on the other hand, the insufficient economy growing can stimulate the search of rent statesmen (as a corruption) and the same results in the origin of institutional traps or increase of charges of intuitional transformation.

Researchers mark that distribution of signs of «institutional crisis took place in Ukraine» [20, p. 68]. Investigation of such crisis is a fall-off of effectiveness of supervisory and regulative functions of the state, accenting of attention of administrative institutes and institutes, on the decision of problems of the own becoming and re-erecting. Institutional transformations are appeared not adequate expectations of citizens.

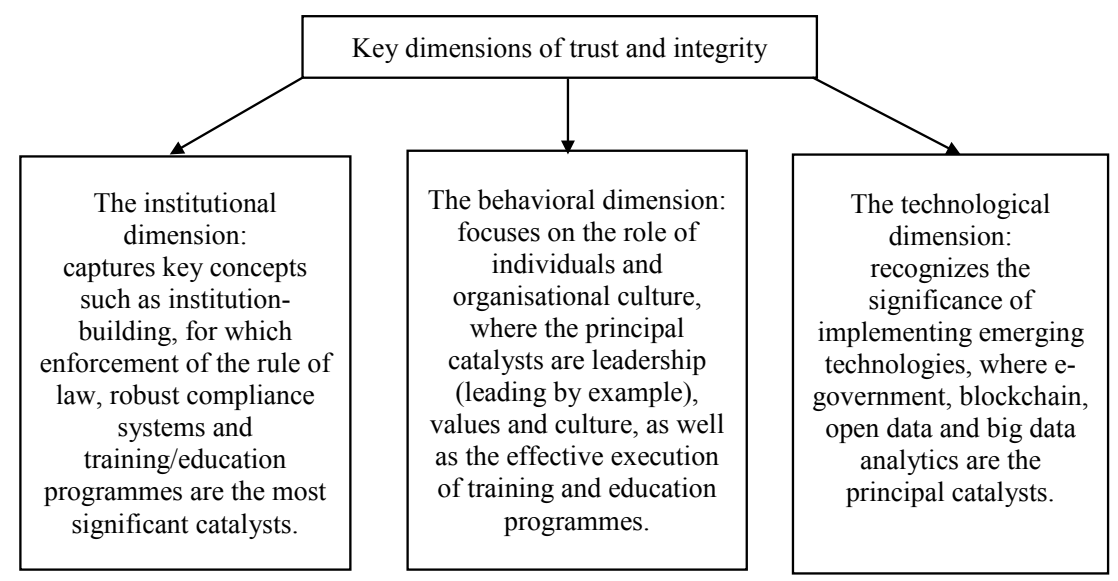

Figure 1. Key dimensions of trust and integrity [17] 
Ukrainian cultural mentality has such features as distrust of political institutions that reflect the practical implementation of state institutions. First of all, this is due to the fact that the population of different regions of the country have different civilizational priorities and vectors of orientation of socio-cultural, mental, value and motivational features. This civilization specificity is primarily due to the peculiarities of mentality, value and political aspirations, which has deep socio-cultural roots [7, p. 248].

Thus, in the current conditions of national development, the formation and strengthening of a cohesive society based on the principle of trust becomes more important. The economic state policy, first of all, should meet these principles and be directed to inclusive development. The formation of trust and integrity is becoming a priority vector of social and economic development.

\section{Institutional component of the economic development}

The special actuality of search of optimal combination of market and state in countries with market transformation acquires. It is very important to conduct reforms on becoming of market economy corresponding to the modern idea about the effective socio-economic system. To provide such development it is necessary to carry out the literate reading of concretelyhistorical context of country, presence of resources, level of preceding development, mentality of people. The all above-stated testifies that quality of institutional environment becomes the center of development, all preconditions and sources intersect and unite exactly in it.

In scientific literature a discussion proceeds in relation to reasons of successes or failures in economic development of one or another country. This discussion developed enplane estimation of the institutional modes on appearance book D. Acemoglu and J. Robinson "Why Nations Fail" in 2012 [1]. Authors distinguish two opposite types of institutes - inclusive and extractive. Most countries are in, to the so-called, «grey zone», i.e. have different combination of afore-named institutes, what affects their economic position and prospects of their development. Undoubtedly, inclusive institutes (including, spreading to wider circle) are more effective, because they encourage the wide participating of people in economic activity and create terms for more motivated appendix of their capabilities and abilities. Among basic descriptions of these institutes it is necessary to distinguish providing of ownership rights, realizations of justice and grant of public 


\section{Chapter «Economic sciences»}

services at level, that would provide equal possibilities for all in education, health protection, choice of professional activity, participating in business. In a difference from inclusive to extractive institutes (extracting), intended for the withdrawal of economic riches, redistribution of him in behalf on the ruling class of elite of society. These institutes perniciously influence on steady economic development in long-term.

The content of discussion is not taken to the different estimation of influence of corresponding institutes on economic development. In that behalf there is rare unanimity among scientific different schools and directions. The sharpness of discussion is concentrated round such aspects of problem as:

1. Are good institutes pre-condition or the result of development.

2. Which criteria of good institutes are, what factors besides institutes and regardless of them can influence on development yet.

3. How good institutes can be created [11, p. 5].

All afore-named aspects of problem are actual for countries with a transformation economy, they acquire the special sharpness for Ukraine. It is coherent with a permanent transformation crisis, with inversion character of becoming of the market system, with the deep falling and destruction of economy as compared to present potential. The «Ukrainian economy showed the real «economic miracle» in negative sense. There was not such case in history, that country which entered on the level of industrial development in the first ten of countries, considerable part of the industrial potential lost in twenty-five years, near third of GDP, that is the worst in the world the result of economic dynamics for this period and entered in the number of the poorest countries of Europe» [8, p. 9].

This situation supposes: at first, careful analysis of reasons happening, and secondly, search of such scenario of development, which would could, overcoming negative tendencies, to show out a country on the trajectory of socio-economic development. There is not a doubt in that reformation must be accompanied such institutional changes which in final analysis will result in establishment of inclusive of the institutional mode. Understanding complication and duration of such process, it is necessary to draw on all reserves of extractive institutes. As history shows these institutes at a competent and patriotically directed elite can give good results in a shortterm prospect. D. Acemoglu makes an example of soviet Russia which at domination extractive society was able to show unprecedented technological 
success of going after type. We pay regard to circumstance that in the past extractive institutes dominated in a historical retrospective view, and a going after type in the conditions of moderate rates of motion of world economy could bring in the end around to the way of speed-up development. A situation in is the world aggravated the process of globalization, carried out in a neo-liberal form. At development of global processes the orientation of development is intensified in a neo-liberal form, centrifugal forces, bearings globalizations from periphery (to the lack of development) to the center, begin to work (to developed). Deepening of integration processes, the new format of placing of productive forces at prevailing of strong players of globalization (TNK, international organizations and other) puts countries with a depression economy and unwithstand institutional environment in unprofitable position. Often these countries lose the economic sovereignty for the sake of decision of short-term tasks, often even not very much perceptible. Thus, the problem of economic sovereignty actualization in the conditions of globalization. He grows into the leading instrument of including of country in global space. Flexibly managing economic sovereignty it is possible to use him for advantageous included in integration groups, using the competitive advantages.

The process of globalization of world economy to a great extent limits ability of national governments to control all economic processes up country, that it is necessary to take into account during the lead through of economic policy of the state. In the conditions of growth of globalization of world economy, the classic instruments of national economic policy, intended for activation of the economy growing and overcoming of the crisis phenomena in an economy, lose the effectiveness to a great extent.

The necessities of economic development enter into contradiction with principle of inviolability of state sovereignty by the that state the scopes of which hinder economic efficiency, on the whole to social progress.

However, obeying financial viability, the states are opened by the scopes, run into the risks of influx of foreign currencies and drugs, international terrorists, streams of information, which act from other countries. All of it unavoidable reduces efficiency of functioning of state machine and compels to search new forms and methods of decision of urgent internal economic and social problems.

In the modern terms of non-linearity of global development and unforeseeable of long-term prognostication, when problems and contradictions 
in an economy accumulate gradually, but them a critical level is preliminary unknown, more detailed study of basic global tendencies and calls world development is needed, that determine the special imperatives for each country. In these terms complication, heterogeneity, vagueness, non-linearity and asymmetries of redistribution of world resources, as major constituents of modern socio-economic global development bring to forming rows over of countries, for which economic globalization appears as high-quality new condition of development, on which already it is practically impossible to influence, but which necessarily need to be taken into account.

The condition of high-quality economic development of country is making of specific national model of economic policy, which must take into account the features of informal rules (national values) of the concrete state. Therefore for forming of effective economic policy in the state it follows to create the own system of institutes, which would be based on the features of national social and cultural capital.

And here it is again appropriate to reminisce role the states in a management sovereignties. Attempt of revision of his role, as T. Piketti marks - not halted from 1970 - 1980th and halted never, as the state plays in economic life a central role which it purchased in post-war decades, fully normally and appropriately, that this role constantly comes into question and becomes under a question [14].

Efficiency of the state will be realized by means of defence of economic interests of all national subjects at the internal market and national economic interests in the international arena.

«The real sovereignty is included by unity of the volitional and practical operating under realization of own interest. Practical realization of such approach, which takes into account interdependence of countries, own interest of subject, objective terms of his realization, in certain historical and institutional terms, dialectical coincides with the decision of tasks of increase of national competitiveness of economy. Than higher competitiveness, the greater is economic freedom of the state and the completer it can be realized economic sovereignty» [8, p. 14].

Carrying out it without the specification of ownership and inclusive of the institutional planning rights is impossible.

Inclusive development in a theoretical relation acquires more complete and system character, and in a practical plan acquires more ramified and steady promotion in breadth and deep into. 
The theory of two methods of institutional organization of company was offered in works of institutionalists (D. North and his coauthors): order of the limited (privileged) access to the resources and order of the opened (free) access to the resources [12].

Inclusive development assists entire countries and world regions to use the results of globalization, economic integration and economy growing. «At good institutes it is possible reliably to retain the high level of economic welfare, but without them even large riches can appear fragile» [13].

The role of economy in a transformational economy is especially noticed, because initiative and managing passing to the market socioeconomic system belongs to the state. As far as becoming of market mechanism the state can pass to the functions the market, foremost in the field of economics. The weakness of civil company at the beginning of transformation period imposes on the state a necessity not only to assist his becoming but also in lining up the institutional mode to take into account interests of all representatives of company. Inclusive development creates possibilities of development, participating in public-useful activity, equal scope social guarantees. That is very important so it that all, that provides a population inclusive institutes so it is arrived at due to the high rates of the economy growing. Effective public production provided in the conditions of the high-explained and well-educated workers in the process of realization of principles of social justice.

It is impossible not to mark that quality of economic institutes is checked up also their ability to grow in a company a trust and to eradicate inequality. Both problems are difficult and requiring the special independent research. In the context of our task it should be marked, that they belong to primary and fundamental, without permission of which inclusive development not to attain.

A trust, as Alen Peyreyfitt marks, - the unique resource, able to convert the desert into Earth, «it is a confidence of members of company in each other and general confidence in the future in which they going to live» [2].

Inclusive comes forward the form of overcoming or softening of inequality, form of social justice. It can provide moderate digging up in a level and quality of life of all layers of company, busy in a public production. Today breaks in property, status and social position, in the level of profits grow in many countries. But especially painfully they are perceived in such countries as Ukraine. At first, because yet not so a long ago these countries behaved to the countries with very moderate social differentiation, and 
secondly, because they are observed in a layers of population of country continues swiftly to grow. Part of households, attributing itself to poor part of population, $72,3 \%$ makes, I.e. almost three fourth companies. On the estimations of experts the size of inequality is off scale. Difference in payment of labour $1 \%$ most well-to-do and $50 \%$ the least well-to-do workers in Ukraine actually high and 43,3 makes time. In Europe - 11,4, in the USA - 24» [15].

Inclusive of development on national and global levels very important and effective for overcoming of crisis and alienation and by virtue of that in modern terms intensified socio-economic, resource, national and cultural, religious, ecological and other problems, global instability grew sharply. Many known scientists come into a notice world public to the necessity of permission of sharp problems of breaks for profits and property position, it is talked about importance of involving of capable of working population in creative activity [14]. The role of the state is undoubtedly great in permission of these major tasks.

Neoinstitutionalists accent attention on that the state will effectively execute the functions only on condition that set them formal norms and system of institutes is in accordance with the folded informal rules and institutes. By other words, the effective state in opinion of T. Eggerstona arises up subject to condition, when a «company on the whole adheres to the social norms, the structure of which coincides with the that structure of rights, which the state aims to support» [6].

The Ukrainian state stands before a thorny problem - to take the deserving place in the global world, to return the lost potential and, leaning against competitive edges, to produce such model of development, which optimum would connect in itself force of the state and market. Time to estimate the own errors came, not to repeat them in future reformation.

O. Soskin in the Ukrainian variant determines main reasons of erroneous reformation:

1. Absence of the correctly formed national economic interests, on realization of which there must be the aimed model of economy which is inculcated in a country.

2. By mistake theoretical subsoil of economic model of development is certain as liberally cosmopolitan conceptions especially monetary direction and automatic observance of advices uncritical perception of experience of their transmitters. 
3. Choice and application of unsuccessful mechanism of realization of general strategy of reforms, by the instruments of which mass voucher privatization of lion's part of public domain, introduction of the system of the elemental pricing, in the same time opening of economy for a non-state export and import, change of legislation of social and economic institutes, which stipulated creation in the country of corruption environment, forming, class corporate groups and their accretion from state bureaucratic by a nomenclature [16].

\section{Conclusion}

In order to create competitive advantages, a favorable environment for innovation is needed, based on the rational use of natural and technological, geo-economic and geopolitical factors. Sustainable competitiveness of the national economy requires a socially just environment in which the human and social capital is continually reproduced through the continuous growth of the welfare and quality of life of the population and a socially responsible business. Creating such an environment lies in the plane of institutional change, the structure of which the state meets. Creating such an environment lies in the plane of institutional change, the structure of which the state meets.

Institutional factors are becoming a leading resource for the competitiveness of the national economy, due to the ability to minimize risks and eliminate uncertainty. This factor plays a special role in the innovative economy, when most of the major sources of productivity increase are exhausted.

The state is one of the most important elements of the system of national institutions, its role in shaping and consolidating the desired level of national competitiveness is due to the exclusive powers of state institutions regarding the fixing of the boundaries of sovereignty with respect to external competitors.

Economic sovereignty is a complete way of organizing the activities of public authorities in an unstable environment of external competition, aimed at ensuring the primacy of national priorities.

Thus, it can be argued that the role of the state in the established mechanisms of competitiveness of the national economy of innovation orientation increases due to the interaction of the market and democracy through an adequate system of institutions that provide motives for innovation activities of business entities. 
Institutions should ensure an active, purposeful attitude of the participants of the economic system towards external competitors, that is to contribute to the formation, development and use of the subjective potential of the economic system.

Properly institutionalized national economy and organized at the level of business entities can take advantage of globalization and resist efforts to conquer the national economic system for the purposes and interests of external actors and interests.

The insufficient level of competitiveness of Ukraine's economy is largely due to the low integrity of the institutional environment, the backwardness of the technological base, the weaknesses in the management of enterprises and corporations, and excessive state interference in the functioning of the economic system. To a large extent, these problems are related to the low potential use of market economy entities.

The activation of institutional mechanisms of freedom and responsibility of economic entities can make a significant contribution to ensuring the growth of national competitiveness.

\section{References:}

1. Acemoglu, D., Robinson, J. (2012). Why nations fail. Available at: http://norayr.am/collections/books/Why-Nations-Fail-Daron-Acemoglu.pdf (accessed 02 February 2019).

2. Bauman, Z. (2000). Liquid Modernity. Available at: https://giuseppecapograssi.files.wordpress.com/2014/01/bauman-liquid-modernity.pdf (accessed 10 February 2019).

3. Christine Lagarde (2018). There's a reason for the lack of trust in government and business: corruption. Available at: https://www.theguardian.com/ commentisfree/2018/may/04/lack-trust-government-business-corruption-christinelagarde-imf (accessed 03 February 2019).

4. Corruption Statistics (2013). Available at: https://www.transparency.org.uk/ corruption/corruptionstatistics/\#.W6vXUPZuLIV (accessed 03 February 2019).

5. Dyba, O., Osadchyi, I. (2014). Vplyv hlobalizatsiyi na sotsial'noekonomichnyy stan Ukrayiny [The influence of globalization on the socio-economic state of Ukraine]. Market of equities in Ukraine, no 7, pp. 19-28.

6. Eggertsson, T. (2003). Economic behavior and institutions. Available at: http://www.library.fa.ru/files/Eggertsson1.pdf (accessed 15 February 2019).

7. Grytsenko, A.A. (2008). Ynstytutsyonal'naya arkhytektonyka y dynamyka эkonomycheskykh preobrazovanyy [Institutional architectonics and dynamics of economic transformations]. Kharkiv: Fort. (in Russian)

8. Grytsenko,A.A. (2016). Ekonomika Ukrayiny na shlyakhu do inklyuzyvnoho rozvytku [Ukraine's economy on the way to inclusive development]. Economy and forecasting, no 2, pp. 9-23 
9. Kolodko Grzegorz, W. (2014). Kuda ydet myr: polytycheskaya эkonomyya budushcheho [Where the world goes: political economy of the future]. Moscow: Magistr. (in Russian)

10. Kutsyk, P.O., Kovtun, O.I., Bashtianyn, G.I. (2015). Hlobal'na ekonomika: pryntsypy stanovlennya, funktsionuvannya ta rozvytku: Monohrafiya [Global economy: principles of becoming, functioning and development: Monograph]. Lviv: Lviv commercial academy. (in Ukrainian)

11. Natkhov, T.V., Polischuk, L.I. (2017). Polytekonomyya ynstytutov y razvytyya: kak vazhno byt' ynklyuzyvnym [Political economy of institutions and development: how important it is to be inclusive]. Moscow: Institute of economics. (in Russian)

12. North, D. (1991). Institutions the Journal of Economic Perspectives, vol. 5, no. 1, pp. 97-112. Available at: https://edisciplinas.usp.br/pluginfile.php/1695541/ mod_resource/content/1/North\%20\%281991\%29.pdf (accessed 30 January 2019).

13. Palacios-Huerta, I. (2016). Cherez 100 let: vedushchye эkonomysty predskazyvayut budushchee. Moscow: Haydara Institute. (in Russian)

14. Piketty, T. (2014). Capital in the Twenty-First Century. Available at: https://dowbor.org/blog/wp-content/uploads/2014/06/14Thomas-Piketty.pdf (accessed 12 February 2019).

15. Sklyarov, R. (2016). Kak preodolet raskol mezhdu elytamy y narodom: put snyzu [How to overcome the split between the elites and the people: the way below]. Zerkalo nedely. Ukrayna, no 41. Available at: https://zn.ua/macrolevel/ kak-preodolet-raskol-mezhdu-elitami-i-narodom-put-snizu-_.html (accessed 14 February 2019).

16. Soskin, O. (2014). Narodnyy kapitalizm: ekonomichna model' dlya Ukrayiny [Popular capitalism: economic model for Ukraine: monography]. Kyiv: IST. (in Ukrainian)

17. World Economic Forum (2018). The Future of Trust and Integrity. Available at: https://www.weforum.org/whitepapers/the-future-of-trust-and-integrity (accessed 15 February 2019).

18. World Economic Forum (2019). The Global Risks Report 2019. Available at: https://www.weforum.org/reports/the-global-risks-report-2019 (accessed 15 February 2019).

19. World Economic Forum (2017). The Inclusive Growth and Development Report. Available at: https://www.weforum.org/reports/the-inclusive-growth-anddevelopment-report-2017 (accessed 15 February 2019).

20. Zhalilo, Y.A. (2012). Pislyakryzovyy rozvytok ekonomiky Ukrayiny: zasady stratehiyi modernizatsiyi [Post-crisis development of the Ukrainian economy: the basics of the modernization strategy]. Kyiv: NISR. (in Ukrainian). 